UDC 327(4):061.1

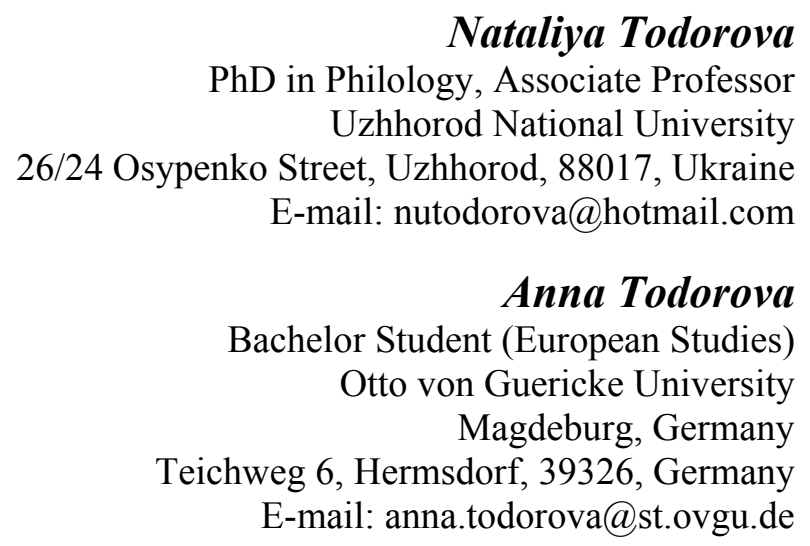

\title{
GLOBALIZATION AND THE ROLE OF THE ENGLISH LANGUAGE
}

In the framework of the linguistic approach to understanding the impact of globalization on the humanity, this paper aims to consider the role of the English language in globalization processes. Given the history of English becoming the world's most widely spoken language, the authors consider possible implications of this fact and overview the current debates and concerns about the role of English and the state of other world languages under conditions of globalization.

Keywords: globalization, lingua franca, Globish, linguistic imperialism, international communication, cross-cultural awareness.

Наталія Тодорова канд. філол. наук, доцент

Ужгородський національний університет 88017, Україна, Ужгород, вул. Осипенко, 26/24

E-mail: nutodorova@hotmail.com

Анна Тодорова студентка бакалавріату (Європейські студії)

Університет Отто фон Геріке, Магдебург, Німеччина

Тейквег 6, Гермсдорф 39326, Німеччина

E-mail: anna.todorova@st.ovgu.de 


\section{ГЛОБАЛІЗАЦІЯ І РОЛЬ АНГЛІЙСЬКОЇ МОВИ}

У рамках лінгвістичного підходу до розуміння впливу глобалізащії на людство автори статті розглядають роль англійської мови в процесах глобалізаиії, а саме намагаються відповісти на питання, яку роль відіграє мова як засіб міжнародного спілкування в поширенні глобалізаиійних процесів у світі; які фактори сприяли розповсюдженню англійської мови як найужсиванішої мови міжнародних відносин; які переваги отримала при цьому світова спільнота та які ризики необхідно враховувати. Відповіді на иі питання мають сприяти глибшому розумінню тієї ролі, яку відіграє наразі англійська мова як одна з робочих мов СС, та можливих викликів, з якими стикається Свропейська спільнота в умовах домінування англійської мови у світі.

Дослідження спирається на фундаментальні роботи провідних учених світу, що дає можливість очінити неоднозначність сучасної наукової думки щзодо питання, яке досліджується, і проаналізувати причини розходжень у думках та суперечок.

Мета та основні питання дослідження зумовили наступну структуру роботи: перша частина висвітлює особливості впливу мови на глобалізачійні прочеси. У другій частині аналізується стан сучасних англомовних досліджень статусу англійської мови як засобу глобальної комунікаиії та формулються передумови глобального домінування англійської мови. Остання частина роботи присвячена дискусіям, які точаться в сучасних наукових колах, щъодо провідної ролі англійської мови в глобалізованому світі.

Незважаючи на зростаючу стурбованість учених та політиків, які вважають розповсюдження англійської мови відповідальним за уніфікачію ідентичності ї̈ багатонаціональних користувачів $i$ звинувачують англомовні держави в мовному імперіалізмі, багато людей сприймають потирення англійської як позитивну річ, символ успіху, зайнятості, якісної освіти тощо. Поточні дискусії про роль англійської як глобальної мови лише доводять, що вона й надалі може й буде домінувати на міжнародній арені, проте усвідомленою стає необхідність належного керівництва, щзо буде сприяти не тільки глобальному взаєморозумінню, але й збереженню місиевого розмаїття та національної ідентичності користувачів англійської мови як мови міжнаціонального спілкування.

Ключові слова: глобалізачія, лінгва-франка, глобіш, лінгвістичний імперіалізм, міжнародне спілкування, крос-культурна обізнаність.

Definition of the problem. Nowadays globalization is one of the buzzwords, which is connected to the information age and digital revolution the 
humanity has recently experienced and continues to face. Apart from usual mass media, such as television or newspaper, the world has experienced the appearance of the Internet, which made the spreading of information much easier and faster. Globalization has influenced many areas of the human life, such as economy, culture, environment or politics. One of the approaches to understanding the impact of globalization on the humanity is a linguistic one, and this paper aims to consider the role of the English language in the process of globalization and to answer the following questions:

- What is the role of international communication and the language as a means of communication in making globalization possible?

- What factors contributed to English becoming the world's most widely spoken language?

- What benefits does this fact give to the global community and what risks should be taken into account?

Answering these questions is expected to provide an insight into the role played by English as one of the working languages in the EU, and possible challenges the European Community has to face regarding to the English language dominance in the world.

The topicality of the issue under research can be proven by its being studied in a number of scientific works, among which are English as a Global Language by David Crystal, English in the Context of International Societal Bilingualism by Joshua Fishman, The Dominance of English as a Language of Science: Effects on Other Languages and Language Communities by Ulrich Ammon, English as a Lingua Franca. Form Follows Function by Alessia Cogo, English as a Global Lingua Franca: A Threat to Multilingual Communication and Translation? by Juliane House and many others cited in the list of references.

The terminological basis is informed by the corresponding articles from Encyclopcedia Britannica Online and Merriam-Webster Dictionary. The historical background has been provided by, for example, The Handbook of the History of English by Ans Van Kemenade and Bettelou Los, the useful video material History of English published by the Open University, and the work by David Crystal mentioned above.

The research questions asked above determined the following structure of this paper. The first part explains the phenomenon of globalization and outlines the importance of the language in globalization processes. The second section analyzes the arguments that prove the status of English as the medium of global communication, and states the preconditions for the global dominance of English. The last part gives an overview of current debates about the role of English in the globalized world. 
1. Globalization and Communicating Globally. To approach the role of English in the modern globalised world this part of the paper starts with the concept of globalization and the role of a language in communicating globally.

As the research has shown, the term globalization has no precise definition, but numerous meanings and interpretations in different areas, such as cultural studies, economics, environment or politics ${ }^{1}$. While some students consider globalization as a social process that makes the currently existing borders irrelevant ${ }^{2}$, others stress the world-unifying, homogenizing power of this process. This term generalized, globalization (which obviously comes from the word "globe") is the "big idea" of $20^{\text {th }}$ century, which contains the process of international integration arising from the exchange of worldwide views, products, ideas, and other aspects of culture and life ${ }^{3}$.

There are also some critical points of view that globalization is in danger of becoming (if it has not already become) the cliché of our times ${ }^{4}$, that there is only the illusion of globalization. However, what cannot be neglected is the occurrence of certain processes spreading the information and experience around the world nowadays, which is, of course, connected to the new era of information and quickly developing new technologies.

According to Chen (2012), five important features of globalization can be traced:

- globalization is a dialectically dynamic process, which is caused by the pushing and pulling between the two forces of cultural identity and cultural diversity, or between local and global;

- globalization is universally pervasive as it penetrates into every aspect of human society and influences the way it lives, thinks, and behaves;

- globalization is holistically interconnected as it builds a huge matrix in which all components are interconnected with networks;

- globalization represents a culturally hybridized state, which allows cultural transmission via new media to take place at a very rapid rate by permeating and dissolving human boundaries;

- globalization increases individual power in the new media society, which pluralizes the world by recognizing the ability and importance of individual components ${ }^{5}$.

These features clearly summarize the opportunities and risks that should be taken into account. On the one hand, the new era of globalization provides us with loads of new opportunities to share and exchange our knowledge, findings, experience or ideas with anyone from another part of the globe. Against a background of rapid technological change, globalization and resulting crosscultural interaction in recent decades has dramatically impacted the types of communication skills needed.

On the other hand, no longer can people afford to simply communicate well within their own homogenous cultures. Today, they need to understand 
the dynamics of long-distance collaboration, the impact of culture on manners of speaking and body language, and how to use technology to communicate with people on the other side of the globe. As globalization has introduced virtual communication and collaboration as a major part of workplace dynamics, it is necessary to understand the challenges of virtual interactions, to be aware of subtle nuances of people's manner of speech when communicating across cultures and of cultural differences in body language, to understand the information needs according to the communication styles of different countries or cultures.

Language as the substance of culture contributes to its formation through vocabulary, greetings or humour, serves as important symbols of group belonging, and forms the people's cultural identity.

Languages are the essential medium of communication in which the ability to act across cultures develops. Mastering several languages enables people to open their personal horizons, to think globally, and to increase their own selfawareness and understanding of their neighbours. Languages are, thus, the very lifeline of globalization: without language (as a means of communication), globalization would have been impossible.

In its turn, globalization has significant effects on language, both positive and negative, which influence the culture of the language in many ways. While allowing some languages and their cultures to spread and dominate on a global scale, globalization is also blamed for leading to the extinction of other languages and cultures.

Among the most obvious effects of globalization on the world's languages the students mention the impact on minority languages, loss of uniformity among the big languages, disregard of linguistic forms and styles richness and diversity, and decline in foreign language learning among English speakers ${ }^{6}$.

To sum up briefly, although not a new phenomenon, globalization has become the increasing trend in all the walks of life. One of the most important components of globalization is international communication, and the worldwide spreading of information would be hardly possible without the language, which is commonly understood and serves as a medium of communication across cultures. Language is basic to social interactions, affecting them and being affected by them ${ }^{7}$. Thus, the significance of the world languages under conditions of globalization is difficult to overestimate, and the following section of the paper looks into the issue of how the world languages respond the globalization challenges and analyzes the pre-requisites of English becoming the main language for communicating globally.

2. English as the Medium of Global Communication. Talking about the significant role of a common language used in the process of globalization, it is 
worth introducing here the term lingua franca, which is relevant when the focus of interest is on common means of communication. As Encyclopaedia Britannica outlines it, this term earlier used to denote a common language consisting of Italian, French, Spanish, Greek and Arabic ${ }^{8}$ which was used for communication among the Europeans and others in non-European locations from the 16th through the early 19th century, and most often this communication was needed in business ${ }^{9}$. Nowadays the term lingua franca also refers to a language that is used among people who speak various different languages and is often applied to the English language. So, terminologically English as a lingua franca has been recognised as a medium of international/ intercultural communication across lingual borders in the modern everyday life. As Robert McCrum in "Globish: How the English Language became the World's Language"(2010) puts it, "thanks to Microsoft, Vodafone, Orange and Apple, this rejuvenated lingua franca has acquired the capacity to zoom through space and time at unprecedented speeds, reaching unprecedented new audiences"10.

Statistically, the role of English in the world can be illustrated by the following facts provided by the British Council:

- English has official or special status in at least 75 countries, with a total population of more than two billion;

- one out of four of the world's population speak English to some level of competence; demand from the other three quarters is increasing;

- more than two thirds of the world's scientists read in English;

- three quarters of the world's mail is written in English;

- 80 per cent of the world's electronically stored information is in English $^{11}$.

As we can see from the bar chart (Figure 1), English is currently the most spoken language in the Internet. This way, it is not only the common language in real life, but also the lingua franca in the global network. The very simple example would be making posts in social networks: if someone is assumed to have a lot of friends on Facebook that are native speakers of different languages, then, if he or she wants all of them to understand what is in the post, the content should be written in English, or the English translation should be added below. Although Facebook has already added the "Translate" function, it cannot be denied that the most universal way to make everyone understand a message is to write it in English.

According to the 2004 Eurobarometer survey, 75 percent of Europeans supported the idea that English is the most useful language to learn, while 69 percent were confident that every EU citizen should speak English ${ }^{12}$. English leads the world both in terms of total speakers as well as being the most commonly studied foreign language ${ }^{13}$.

The leading role of English as a common medium for international communication is also supported by the following commonly recognized facts. 


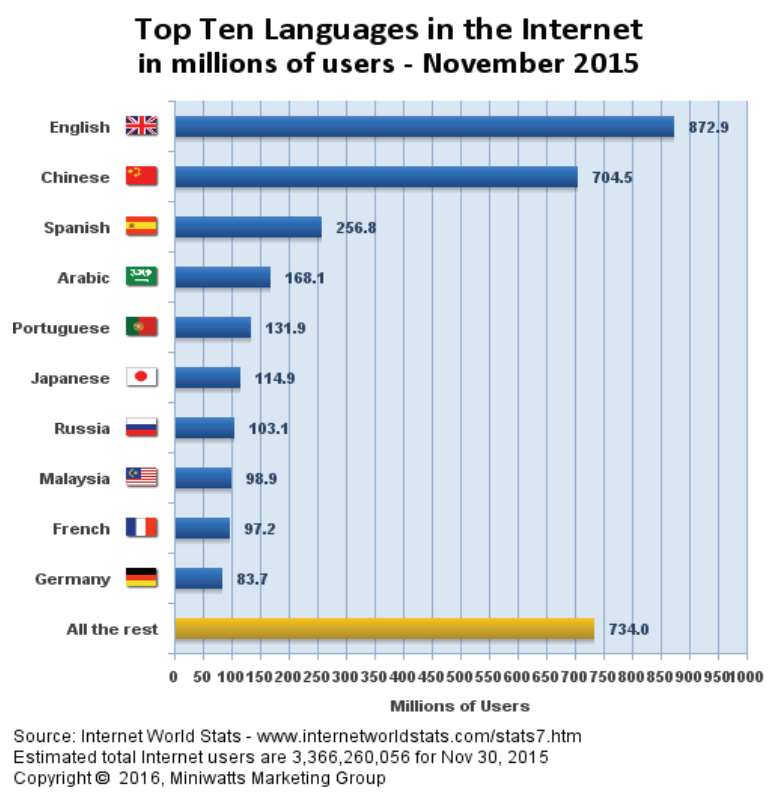

Figure 1 - Top Ten Languages in the Internet, in millions of users (state November 2015), Source: Internet World Stats.

First, English has established itself as the international language of business and commerce ${ }^{14}$, and it is increasingly true as international trade expands extensively, bringing new countries into contact. English has been also used in international logistics, such as air traffic control, as a common language ${ }^{15}$. As an example, it can also be mentioned that many of the best MBA (the Master of Business Administration) programs worldwide are taught in English ${ }^{16}$, so the adequate communicative competence in English provide the companies' managerial staff with an opportunity to enjoy the best quality professional training. Multinational companies require a certain degree of English proficiency from potential employees. It means that more and more people nowadays learn English in order to get the best possible professional training and employment opportunities with top companies. Good English is also very important for mass media, journalists and writers, as it provides them with the opportunity to reach wide audience all over the world, and to get the urgent information from international resources worldwide.

Second, outside Europe English is the predominant language of international politics. After the centuries, when the international communication existed with help of translators, the humanity felt an urgent need in the lingua franca in the $20^{\text {th }}$ century, when a number of great international organisations appeared, such as the United Nations (1945), the World Bank (1945), UNESCO and UNICEF (1946), the World Health Organisation (1948), 
International Atomic Energy Agency (1957), the European Union (1993) and other. Although the United Nations and its various agencies have more than one working language, more often than not, English comes to be chosen as the preferred one for communicating among the participating member-nations ${ }^{17}$.

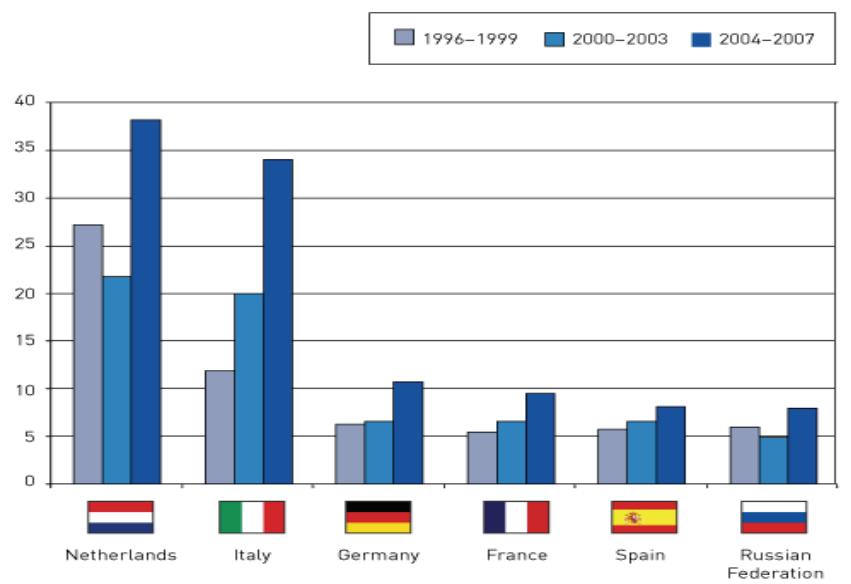

Figure 2-Ratio of the number of journal articles published by researchers in English to those in the official language in six European countries, 1996-2007 ${ }^{18}$.

English is also the increasingly dominant language of science and medicine $^{19}$, as much of the technical terminology is based on English words. Moreover, in order to learn state-of-the-art developments and discoveries from around the world one has to be able read about them in journals and research reports, which are most likely published in English, no matter which country the scientists come from (see Figure 2). The bar-chart shows that the number of publications in English has increased in all six given countries during the period 1996-2007, and continues increasing nowadays. And, of course, good conversational English makes important contacts at conferences and seminars possible.

Besides, English opens doors to the academia. As an example, if the best program in some field is in an English-speaking country, English will give an opportunity to get enrolled and to take classes from the world-class scholars. Apart from this, the key steps to success in academia are to attend international conferences and to get published in foreign journals. For this purpose, excellent English is also essential. To avoid going far away in search of examples, we could take Magdeburg, as the "academic city". Many students without proper German skills are still able to study at the Otto-von-Guericke University, as due to the internationalization of higher education there are study programs that are taught in English, like International Study Programs in Management and Economics ${ }^{20}$; and bilingual programs, like, for example, European Studies. 
Furthermore, English is often used for educating the wide walks of society and increasing the average level of English among common people through mass media, like television or the Internet. Many Internet sites nowadays provide useful resources for learning English, many articles with useful tips, key phrases, vocabulary or grammar for English-learners are posted in social nets every day, which makes learning English more affordable and much easier. To give an example of educating the average TV audience, one of the main Ukrainian TV channels named $1+1$ has recently started showing series in English with subtitles. This gives people an additional enjoyable opportunity to practice their understanding of a foreign language. To add up, the national governments introduce the language policy to promote the English language learning among the country's population, as for, example, it has been done in Ukraine, where the year of 2016 was officially declared to be the "Year of English".

The world leading role of English nowadays has been preconditioned by this language historic background. The study by one of the most authoritative modern linguists, David Crystal, called English as a Global language gives a detailed overview of spreading of English around the globe. In terms of space, all this impressive history will not be considered, but it is worth having a look on the main stages which made it possible.

To begin with, the world languages, and the English language as well, have always been on move, as Crystal outlines. Since the fifth century, the English language began to spread firstly in the regions of Wales, Cornwall, Cumbria and Southern Scotland, traditionally the strongholds of the Celtic languages ${ }^{21}$. Then English spread around Scotland, as after the Norman invasion of 1066 many nobles from England fled north. And, finally, Ireland fell under the English rule when Anglo-Norman knights were sent across the Irish Sea.

The following development of English was related to many historical events and periods, such as the reign of the King William the Conqueror which integrated many French words into English, or the period when Shakespeare lived and invented about two thousand new words and phrases in English, etc. ${ }^{22}$.

The language has been developing mainly inside the British Isles until the end of $16^{\text {th }}$ century, when there was already between 5 and 7 million of native speakers. After developing for almost a millennium on the British Isles, English was taken around the world by the sailors, soldiers, pilgrims, traders and missionaries of the British Empire. They transferred English to America, Canada, The Caribbean, Australia, New Zealand, South Africa, South Asia and other regions of the world. But the most significant transfer of English took place in America, as between $16^{\text {th }}$ century and the beginning of Elizabeth the second's reign in 1952 the number of English-speaking people increased to about 250 million, most of whom were and remain the Americans ${ }^{23}$. 
As David Crystal outlines, it was not only England which influenced the development of the English language in America. Through centuries the territory was occupied by the Spaniards, the French, the Dutch and the Germans. There were increasing numbers of Africans entering the south, as a result of the slave trade. The nineteenth century experienced a massive increase in American immigration, as people fled from Europe because of revolutions, poverty, and famine. Within one or two generations of arrival, most of these immigrant families had come to speak English, through a natural process of assimilation, and the result was a massive growth in mother-tongue use of English.

If we talk about other areas of English influence, in most of the British Empire, the main goal was trade. That was why so few Britons actually settled. This explains why English did not come to dominate colonies in Asia and Africa, where it was the language of business, administration and education, but not the language of the people. For a long time, access to English meant access to education, whether in the mission schools in Africa or the first universities in India. This created the English-speaking elite in most countries.

In countries where large settler colonies were formed, such as Australia, Canada and the USA, native languages and cultures have been pushed to nearextinction by the presence of English. And, as recently as the $19^{\text {th }}$ century, English was not the world's lingua franca (as the term suggests, French was the number one language of international communication). Without the rise of the USA in the $20^{\text {th }}$ century, the world's language landscape would look very different. And English as the new lingua franca, awkwardly christened "Globish" in 1995 by amateur linguistics scholar Jean-Paul Nerrière, was not the language of England and the English, but that of America and Americans for the reasons of history and economics, and due to the IT revolution and the Internet, and the fact that "the Highway Code of this teeming information freeway was written in American English"24.

To organize all that has been said above, the present-day world status of English is primarily the historic result of two factors:

- expansion of British colonial power, which peaked towards the end of the nineteenth century, and

- emergence of the United States as the leading economic and political power of the twentieth century. The US has nearly 70 per cent of all English mother-tongue speakers in the world.

Besides, the world dominance of the English language has been objectively supported by its established status as the main language of business, politics, science and education, as a lingua franca for communicating among world nations and various cultures in various contexts. 
3. Lingua Franca or Linguistic Imperialism? The world-leading role of the English language explained and exemplified, it is necessary further to consider the possible implications of this fact and to give an overview of the current debates and concerns about the role of English and the state of other world languages under conditions of globalization. While many people perceive the spread of English as a positive thing, a symbol of employment, education, modernity, and technology, there are growing concerns among the students who hold the spread of English responsible for homogenizing the peoples' identities and interests. They claim that global English tends to equalize values and desires, without doing the same for opportunities ${ }^{25}$.

The singular position of the English language in the modern world gave rise to the following lines of debates based on the positive and negative effects of the language spread, as summarized by Anne Johnson ${ }^{26}$ :

- Should the rise of English be understood as a powerful economic tool for development and commerce, or as a dangerous mechanism reinforcing (and creating new) inequalities based on English-proficiency?

- Does English serve as a carrier of culture and a tool for cross-cultural communication and awareness, or as a force of cultural imperialism and homogenization?

- Is the pre-eminence of the English language as a lingua franca nothing more than a passing phase, similar to lingua francas of the past, or does its rise under conditions of fast-paced globalization mean that it is a more permanent, and potentially more dangerous, phenomenon?

The first line of debate, on the one hand, acknowledges the role of the English language as a powerful development tool throughout the world, and a pre-condition for many people's being competitive, and thus successful, in the labour market. As Anne Johnson concludes ${ }^{27}$, "proficiency in English has become a commodity, valuable both because of its utility as a "basic skill of modern life comparable with the ability to drive a car," ${ }^{28}$ and for its image as "a form of cultural capital" "29. On the other hand, the opponents claim that English-only approach violates the equality of opportunities, and lingual and cultural rights of other language speakers, like other human rights, should be protected $^{30}$.

The second area of disagreement deals with the language as a carrier of culture. Proponents of English as a lingua franca emphasize that global English becomes detached from its culture of origin and actually facilitates a crosscultural dialogue.

As the global language system is very much interconnected, linked by multilingual persons who hold the various linguistic groups together, and English is distinguished from the other languages by having very significant numbers of non-native speakers, the researchers come to conclusion that 
English is going to be the one most affected by globalization ${ }^{31}$, and this effects are not undoubtedly positive.

English as a lingua franca (ELF) is even taught in a specific way. According to Paradowski ${ }^{32}, \mathrm{Cog}^{33}$ and Firth $^{34}$, ELF interactions concentrate on function rather than form. In other words, communicative efficiency (i.e. getting the message across) is more important than correctness. As a result, ELF interactions are very often hybrid. Cogo and Dewey ${ }^{35}$ also outline that speakers accommodate to each other's cultural backgrounds and may also use code-switching into other languages that they know. With a view on the Vienna-Oxford International Corpus of English (VOICE) ${ }^{36}$ and additional research $^{37}$, some specific features of ELF lexis and grammar have already been identified, such as: (a) a shift in the use of articles (with some preference for zero articles); (b) invariant question tags; (c) treating 'who' and 'which' as interchangeable relative pronouns; (d) shift of patterns of preposition use; (e) preference for bare and/or full infinitive over the use of gerunds; (f) extension to the collocational field of words with high semantic generality; $(\mathrm{g})$ increased explicitness; and so on.

These features can be just registered as a result of the language simplification to facilitate the communication among non-native speakers by means of 'Globish'; however, they can be also critically considered as the set of errors, bad style, or even illiteracy rather than the unique way of representing someone's culture through speaking this way.

Thus, globalization may well have a kind of revenge effect on the English language, actually undermining the position of the English native speakers who, by virtue of having a mastery of this obviously valuable language, think they are in a strong position. Some researchers emphasize that the preeminence of English also results in the potentially catastrophic monolingual arrogance of Americans, from top government leaders to a man in the street ${ }^{38}$. With such a large domestic market (over 225 million people) and English as the global language for business, many Americans assume that they neither need to speak other languages nor go to other countries to succeed in the corporate world. This parochialism of the Americans may be perceived as 'deglobalization' for the nation and has already proven to be defeating both in business and in social interactions.

The opposite side in the second, cultural line of argument blames the English language for being an imperialist and homogenizing force that levels cultural diversity worldwide and imposes "Americanized "cosmopolitanism" More often than not, English is, thus, named to be a threat to multilingualism in Europe and overseas. However, many researchers question these assumptions: take, for example, Juliane House's idea of the compromise ${ }^{40}$, the 'third way', also described by Fishman ${ }^{41}$ as 'additional language', functioning not against, but in conjunction with, local languages. 
Besides, awareness of the potential threat to minority languages under conditions of lingual globalization inspired many national governments to launch special policies to promote minority languages and to fight linguistic imperialism $^{42}$ and parochialism in order to counter-balance the cultural influence of the English language on the world community. The Common European Framework of Reference for Languages (2001) is a vivid example of such a program document aimed at promoting language diversity in Europe and supporting minority languages by giving equal support to all the EU languages.

And finally, the third line of debate focuses on how permanent, and thus potentially threatening, the global dominance of the English language is going to be. Some scholars maintain that "there are many reasons to believe that the heyday of the English language will not long outlive the powers that have propelled it to the fore" ${ }^{43}$. The pessimistic forecast is balanced by the basic human tendency to resist domination and the registered trend that many lingual groups are pushing to protect lingual diversity. The fact that regional lingua francas like Arabic, Chinese, or Spanish, remain more effective than English tools for wide walks of local communities cannot be denied as well. Hence, this line of argument deals with the scope of political, social and cultural effects the world dominance of English may result in. What both debating parties agree about is that this issue is not so simple to ignore.

The debates summarized above, however acute and controversial they may seem, support the obvious significance of the English language for the world community, and recognize it as a basis for international communication which should be used for the benefit of the mankind. They also illustrate the awareness of the global community that impact of a global language is not unambiguous and should be kept under thorough supervision in order to minimize its homogenizing force and to preserve cultural diversity worldwide.

Conclusion. Having in mind everything mentioned above it can be concluded that globalization (despite existing scepticism) has become a reality of modern life. Without doubt, one of the most important components of globalization is international communication, and the worldwide spreading of information would be hardly possible without language, which is basic to international and intercultural social interactions. Thus, the significance of the world languages under conditions of globalization is difficult to overestimate.

As the result of the expansion of British colonial power and the emergence of the United States as the leading economic and political power, English has become the medium of intercultural communication, taking the leading role in world business, science, popular culture, mass media etc. This trend was further developed by English-mediated technologies and the internet. Although there are growing concerns among the students and politicians who hold the 
spread of English responsible for homogenizing the peoples' identities and interests and blame it for linguistic imperialism, many people perceive the spread of English as a positive thing, a symbol of success, employment, education, modernity, etc. On-going debates on the role of English as a global language only prove that it may function under good governance for the sake of promoting global understanding and preserving local diversity.

${ }^{1}$ Watson James L. Cultural globalization. Encyclopcedia Britannica Online. Retrieved 21 January, 2016, from URL: http://www.britannica.com/science/cultural-globalization.

${ }^{2}$ Steger, Manfred B. Globalization: A Very Short Introduction. Oxford University Press, 2003. 168 p.

3 Al-Rodhan R.F. Nayef/ Stoudmann, Gérard (2006): Definitions of the Globalization: A Comprehensive Overview and a Proposed Definition.

${ }^{4}$ Held David/ McGrew, Anthony/ Goldblatt, David/ Perraton, Jonathan (1999): Global Transformations. Available at URL: https://www.polity.co.uk/global/whatisglobalization.asp [21.01.2016].

${ }^{5}$ Chen Guo-Ming. (2012). Impact of new media on intercultural communication. China Media Research, 8 (2 April), p. 3.

${ }^{6}$ De Swaan, Abram (2001): Globalization and Its Effect on the World's Languages. Available at URL: http://www.transpanish.biz/translation_blog/globalization-and-its-effect-onthe-world $\% \mathrm{E} 2 \% 80 \% 99$ s-languages/

${ }^{7}$ Eble, Connie (2016) Sociolinguistics Basics Available at URL: http://www.pbs.org/ speak/speech/sociolinguistics/sociolinguistics/.

${ }^{8}$ Mufwene Salikoko Sangol (2016): lingua franca. From: Encyclopcedia Britannica Online. Retrieved 20 January, 2016 from URL: http://www.britannica.com/topic/lingua-franca.

${ }^{9}$ Lingua Franca. Merriam-Webster.com. Accessed January 20, 2016. Available at URL: http://www.merriam-webster.com/dictionary/lingua franca.

${ }^{10}$ McCrumb Robert. Globish: How the English Language Became the World's Language. W. W. Norton \& Company. 2010. P.46.

${ }^{11}$ English language: Facts and Figures. Available at URL: http://www.englishenglish. com/english_facts.htm

12 European Union, European Commission, Directorate General for Press and Communication: Many Tongues, One Family: Languages in the European Union. Brussels, 2004.

${ }^{13}$ A World Empire by Other Means - The Triumph of English; The English Language. (The Spread of English). The Economist 22 Dec. 2001. [Electronic version]. Retrieved from URL: https://www.highbeam.com/doc/1G1-81118386.html.

14 Tsedal Neeley. Global Business Speaks English. Harvard Business Review. 2012. Available at URL: https://hbr.org/2012/05/global-business-speaks-english [05.2012].

15 Hobbs, F.D. Traffic control. Encyclopaedia Britannica Online. 2016. Retrieved 21 January, 2016. Available at URL: http://www.britannica.com/technology/traffic-control

${ }^{16}$ FindMBA: What is an MBA? Basic information about the Master of Business Administration degree. 2016. Available at URL: http://find-mba.com/what-is-an-mba.

17 Thirumalai M.S. English as an International Language, from: "An Introduction to TESOL. Teaching English to Speakers of Other Languages". Thirumalai, M. S. Ph.D. / Mallikarjun, B. Ph.D.: Language in India. 2002. Volume 2. Available at URL: http://www. languageinindia.com/april2002/tesolbook.html. 
${ }^{18}$ Research Trends. English as the international language of science. Research Trends. 2008. Issue 6. Available at URL: http://www.researchtrends.com/issue6-july-2008/english-asthe-international-language-of-science/ [07.2008].

${ }^{19}$ Ammon Ulrich. The Dominance of English as a Language of Science: Effects on Other Languages and Language Communities. Walter de Gruyter. 2001. 491 p.

20 OVGU, The International Study Program in Management and Economics (2016). Available at URL: http://www.manec.ovgu.de/.

${ }^{21}$ Crystal David. English as a Global Language, $2^{\text {nd }}$ Edition. Cambridge University Press, 2012. Pp. 1-35.

${ }^{22}$ Ibidem.

${ }^{23}$ Ibidem.

${ }^{24}$ Levy Paul. The Language of Globalization. The Wall Street Journal, May 28, 2010. Available at URL: http://www.wsj.com/articles/SB10001424052748704269204575271033235 629568.

${ }^{25}$ Delhumeau Herve. Language and Globalization (July 22, 2011). Available at URL: https://hdelhumeau.wordpress.com/2011/07/22/language-and-globalization/.

${ }^{26}$ Johnson Anne. "The Rise of English: The Language of Globalization in China and the European Union". Macalester International. 2009. Vol. 22. Article 12. P. 132-141. Available at URL: http://digitalcommons.macalester.edu/macintl/vol22/iss1/12.

${ }^{27}$ Ibidem.

${ }^{28}$ After Babel, a New Common Tongue. The Economist (August 7, 2004). Available at URL: http://www.economist.com/node/3064790.

${ }^{29}$ Short John Rennie, Boniche Armando, Kim Yeong, Li Li Patrick. (2001) "Cultural Globalization, Global English, and Geography Journals". The Professional Geographer 53, 2001. No. 1. P. 1-11.

${ }^{30}$ Johnson Anne (2009).

${ }^{31}$ Delhumeau Herve. Language and Globalization (July 22, 2011). Available at URL: https://hdelhumeau.wordpress.com/2011/07/22/language-and-globalization/

${ }^{32}$ Paradowski Michał B. Review article on "Understanding English as a Lingua Franca: A Complete Introduction to the Theoretical Nature and Practical Implications of English used as a Lingua Franca" by Barbara Seidlhofer. The Interpreter and Translator Trainer 7(2) Special Issue: English as a Lingua Franca. Implications for Translator and Interpreter Education. 2013. P. 312-20.

${ }^{33}$ Cogo Alessia, Dewey Martin. Efficiency in ELF communication. From pragmatic motives to lexico-grammatical innovation. Nordic Journal of English Studies. 2006.

${ }^{34}$ Firth Alan. The lingua franca factor. Intercultural pragmatics. 2009. 6: 2. P. 161-163.

${ }^{35}$ Cogo Alessia, Dewey Martin (2006).

${ }^{36}$ VOICE (Vienna-Oxford International Corpus of English): FAQ. Available at URL: http://www.univie.ac.at/voice/page/faq.

${ }^{37}$ Simpson Davies, Katy Patsko, Laura. How to teach English as a lingua franca (ELF). 2013. Available at URL: https://www.britishcouncil.org/voices-magazine/how-teach-englishlingua-franca-elf [23.10.2013].

${ }^{38}$ Adler Nancy J., Gundersen Allison. International Dimensions of Organizational Behavior, Cengage Learning. 2007. P. 14.

39 Johnson Anne (2009).

${ }^{40}$ House Juliane. English as a global lingua franca: A threat to multilingual communication and translation? Journal of Sociolinguistics 7-4, 2003. P. 556-578.

${ }^{41}$ Fishman Joshua A. English in the context of international societal bilingualism. Joshua A. Fishman, Robert Cooper and Andrew Conrad. (Eds.). The Spread of English, Rowley, Massachusetts: Newbury House, 1977. P. 329-336. 
${ }^{42}$ Phillipson R. Linguistic Imperialism. Oxford: Oxford University Press, 1992.

${ }^{43}$ Johnson, Anne. 2009. P. 41.

\section{REFERENCES}

1. A World Empire by Other Means - The Triumph of English; The English Language. (The Spread of English). (2001). The Economist. Dec. 22. Retrieved from https://www. highbeam.com/doc/1G1-81118386.html [in English].

2. Adler, Nancy J., \& Gundersen, Allison. (2007). International Dimensions of Organizational Behavior, Cengage Learning [in English].

3. After Babel, a New Common Tongue. (2004). The Economist. August 7. Retrieved from http://www.economist.com/node/3064790 [in English].

4. Al-Rodhan, R.F. Nayef, \& Stoudmann, Gerard. (2006). Definitions of the Globalization: A Comprehensive Overview and a Proposed Definition [in English].

5. Ammon, Ulrich. (2001). The Dominance of English as a Language of Science: Effects on Other Languages and Language Communities. Walter de Gruyter [in English].

6. Cogo, Allessia. (2008). English as a Lingua Franca. Form follows function. English Today 95 (3), 58-61 [in English].

7. Cogo, Alessia, \& Dewey, Martin. (2006). Efficiency in ELF communication. From pragmatic motives to lexico-grammatical innovation. Nordic Journal of English Studies [in English].

8. Chen, Guo-Ming. (2012). Impact of new media on intercultural communication. China Media Research, 8 (2 April), 3 [in English].

9. Crystal, David. (2012). English as a Global Language, $2^{\text {nd }}$ Edition. Cambridge University Press [in English].

10. Day, Robert A., Sakaduski, Nancy, \& Day, Nancy (Eds.). (2011). Scientific English: A Guide for Scientists and Other Professionals. Third Edition, ABC-CLIO [in English].

11. De Swaan, Abram. (2001). Globalization and Its Effect on the World's Languages. Retrieved from http://www.transpanish.biz/translation_blog/globalization-and-its-effect-onthe-world\%E2\%80\%99s-languages/ [in English].

12. De Swaan, Abram. (2001). Words of the World. The Global Language System. Malden, MA: Blackwell Publishers [in English].

13. Delhumeau, Herve. (2011). Language and Globalization. July 22. Retrieved from https://hdelhumeau.wordpress.com/2011/07/22/language-and-globalization/ [in English].

14. Eble, Connie. (2016). Sociolinguistics Basics. Retrieved from http://www.pbs.org/ speak/speech/sociolinguistics/sociolinguistics/ [in English].

15. English language: Facts and Figures. Retrieved from http://www.englishenglish. com/english_facts.htm [in English].

16. European Union, European Commission, Directorate General for Press and Communication (2004). Many Tongues, One Family: Languages in the European Union. Brussels [in English].

17. FindMBA: What is an MBA? Basic information about the Master of Business Administration degree (2016). Retrieved from http://find-mba.com/what-is-an-mba [in English].

18. Firth, Alan. (2009). The lingua franca factor. Intercultural pragmatics. 6: 2, 147-170 [in English].

19. Fishman, Joshua A. (1977). English in the context of international societal bilingualism. Fishman, Joshua A., Cooper, Robert, \& Conrad, Andrew. (Eds.). The Spread of English, Rowley, Massachusetts: Newbury House [in English]. 
20. Hartmann, R. R. K. (1996). The English Language in Europe, Intellect Books [in English].

21. Hjarvard, Stig. The Globalization of Language How the Media Contribute to the Spread of English and the Emergence of Medialects. Retrieved from http://denizo.opia.dk/ la.trezorejo/alilingve/hjarvard.The.Globalization.of.Language.pdf. [in English].

22. Held, David, McGrew, Anthony, Goldblatt, David, \& Perraton, Jonathan. (1999). Global Transformations. Retrieved from https://www.polity.co.uk/global/whatisglobalization. asp [21.01.2016] [in English].

23. Hobbs, F.D. (2016). Traffic control. Encyclopcedia Britannica Online. Retrieved from http://www.britannica.com/technology/traffic-control [in English].

24. House, Juliane. (2003). English as a global lingua franca: A threat to multilingual communication and translation? Journal of Sociolinguistics, 7-4, 556-578 [in English].

25. Johnson, Anne. (2009). The Rise of English: The Language of Globalization in China and the European Union. Macalester International. Vol. 22, Article 12, 132-141. Retrieved from http://digitalcommons.macalester.edu/macintl/vol22/iss1/12 [in English].

26. Levy, Paul. (2010). The Language of Globalization. The Wall Street Journal. May 28. Retrieved from http://www.wsj.com/articles/SB1000142405274870426920457527103323562 9568 [in English].

27. Lingua, Franca. (2016). Merriam-Webster.com. Retrieved from http://www.merriamwebster.com/dictionary/lingua franca [in English].

28. McCrumb, Robert. (2010). Globish: How the English Language Became the World's Language W. W. Norton \& Company [in English].

29. Mufwene, Salikoko Sangol. (2016). Lingua franca. Encyclopcedia Britannica Online. Retrieved from http://www.britannica.com/topic/lingua-franca [in English].

30. Open University: History of English (combined). Retrieved from https://www. youtube.com/watch?v=H3r9bOkYW9s [in English].

31. OVGU, The International Study Program in Management and Economics. (2016). Retrieved from http://www.manec.ovgu.de/ [in English].

32. Paradowski, Michał B. (2013). Review article on Understanding English as a Lingua Franca: A Complete Introduction to the Theoretical Nature and Practical Implications of English used as a Lingua Franca by Barbara Seidlhofer. The Interpreter and Translator Trainer 7(2). Special Issue: English as a Lingua Franca. Implications for Translator and Interpreter Education [in English].

33. Phillipson, R. (1992). Linguistic Imperialism. Oxford: Oxford University Press [in English].

34. Research, Trends. (2008). English as the international language of science. Research Trends. Issue 6. Retrieved from http://www.researchtrends.com/issue6-july-2008/english-asthe-international-language-of-science/ [07.2008] [in English].

35. Seidlhofer, Barbara. (2006). Towards making Euro-English a linguistic reality. Bolton, Kinglsey, \& Kachru, Braj B. (Eds.). World Englishes. Critical Concepts in Linguistics. (Vol. III). London: Routledge [in English].

36. Simpson Davies, Katy, \& Patsko, Laura. (2013). How to teach English as a lingua franca (ELF). Retrieved from https://www.britishcouncil.org/voices-magazine/how-teachenglish-lingua-franca-elf [23.10.2013] [in English].

37. Short, John Rennie, Boniche, Armando, Kim, Yeong, \& Li Li, Patrick. (2001). Cultural Globalization, Global English, and Geography Journals. The Professional Geographer 53, 1, 1-11 [in English].

38. Steger, Manfred B. (2003). Globalization: A Very Short Introduction. Oxford University Press [in English]. 
39. Tardy, C. (2004). The role of English in scientific communication: lingua franca or Tyrannousaurus rex? Journal of English for Academic Purposes. Vol. 3. No. 3, 247-269 [in English].

40. Thirumalai, M. S. (2002). English as an International Language. An Introduction to TESOL. Teaching English to Speakers of Other Languages. Thirumalai, M. S. Ph.D., Mallikarjun, B. Ph.D. Language in India. (Vol.2). Retrieved from http://www.languageinindia. com/april2002/tesolbook.html [in English].

41. Tsedal, Neeley. (2012). Global Business Speaks English. Harvard Business Review. Retrieved from https://hbr.org/2012/05/global-business-speaks-english [05.2012] [in English].

42. Van Kemenade, Ans, \& Los, Bettelou. (Eds.). (2009). The Handbook of the History of English. John Wiley \& Sons [in English].

43. VOICE (Vienna-Oxford International Corpus of English). FAQ. Retrieved from http://www.univie.ac.at/voice/page/faq [in English].

44. Watson, James L. (2016). Cultural globalization. Encyclopcedia Britannica Online. Retrieved from URL: http://www.britannica.com/science/cultural-globalization [in English]. 